FACTA UNIVERSITATIS

Series: Law and Politics Vol. 18, No3, 2020, pp. 225-231

https://doi.org/10.22190/FULP2003225S

Review Paper

\title{
STALKING: THEORETICAL FRAMEWORK
}

\author{
UDC 343.434/.436
}

\section{Milica Stanković}

\author{
Faculty of Law, University of Niš, Serbia
}

\begin{abstract}
In recent years, the criminal offence of stalking has drawn considerable attention of scientific and professional public. Stalking has been recognized as a criminal offence and a serious social problem since the 1990s. Before that, no state or society had statutes that recognized stalking as a criminal offence. It does not suggest that stalking did not exist before the 1990s. Stalking has always been part of human relations. Prior to enacting the legislation on stalking, many forms of unlawful behavior indicative of stalking were legally considered as harassment. Notably, the media portrayal of celebrity stalking was the catalyst that first exposed the presence of such intrusive behavior and triggered global interest. Based on the prior research on stalking, the author of this paper provides an overview of the criminal offence of stalking, outlines the primary arguments for its incrimination, and summarizes its principle characteristics.
\end{abstract}

Key words: stalking, criminal offence, phenomenon, characteristics

\section{INTRODUCTION}

In general, stalking may be regarded both as an old and a new phenomenon. Literature, art, movies, newspapers, comic books, television programs and songs show that the incidence of stalking has been part of the human society for two thousand years. Some literary works (e.g. Dante's Purgatory, Dickens's Bleak House) and movies (e.g. Play Misty for Me, Fatal Attraction, or Prohibited Photos) show patterns of behavior that are considered stalking (Ristanović Nikolić, Lepojić Kovačević, 2007: 3).

The criminal offence of stalking has been part of the criminal justice system for less than a decade. Stalking was first enacted as a criminal offence in California, after the murder of a young actress Rebecca Schaeffer who was shot to death by an obsessed fan. The murder of Rebecca Schaeffer and four other women within a month and a half demonstrated the inadequacy of the existing criminal justices system in addressing the forms of unlawful conduct which comprised a pattern of stalking and potential social risks. In each of these cases, the stalked women had sought restraining orders, and each of them

Received October $15^{\text {th }} 2020 /$ Accepted November $23^{\text {th }}, 2020$

Corresponding author: Milica Stanković, LL.M., ${ }^{*} \mathrm{PhD}$ student, Faculty of Law, University of Niš; Judicial Assistant at the Appelate Court of Niš. E-mail: milica.stankovic@ni.ap.sud.rs 
had communicated to others the fear that she would be killed. Two years after the adoption of the California Penal Code (1990) ${ }^{1}$, stalking was criminalized in the penal codes of over half of the states in the USA. By 1998, all fifty states had laws on stalking. ${ }^{2}$ National studies show that the prevalent stalking rate reached $12 \%$ for women and $4 \%$ for men. For women, it means that over 1.6 million women in America are stalked every year (Tjaden, Thoennes, 1998: 134).

European countries introduced the criminal offence of stalking in their criminal laws a decade later. It was commonly justified by the view that general criminal law terms (such as: the use of force, threats and coercion), in conjunction with the existing legal provisions, are sufficient to ensure adequate protection against such conduct. An exhaustive research in European countries showed significant differences in legislative solutions, particularly in terms of the commission of this act, the perpetrator's intent and the potential penalty (Van der Aa, 2017: 111).

In this paper, the author provides an overview of the criminal offence of stalking, outlines the primary arguments for its incrimination, and provides a detailed analysis of the elements of the crime of stalking.

\section{DEFINITON OF STALKING}

Most definitions of stalking in relevant criminal law literature are rather broad. Thus, stalking is broadly defined as "the act of following, viewing, communicating with, or moving threateningly or menacingly toward another person" (Wright, Burgess, Burgess, Laszlo, McCreary, Douglas, 1996: 487). The typical requirement in these definitions is the presence of intrusive and harassing behavior on two or more occasions (Sheridan, Gillet, Davies, 2002: 301). Relying on the definition of stalking provided in the California Penal Code, Meloy and Gothard (1995) define stalking as "the willful, malicious, and repeated (obsessional) following and harassment of another person that threatens his or her safety" (Meloy and Gothard, 1995: 259).

While most researchers provide definitions of stalking, others have chosen to exclude a definitive description of all forms of conduct, thus allowing researchers to interpret individual definitions (Emerson, Ferris, Gardner, 1998: 290). Some definitions of stalking include components of intent, fear, threats, and danger (Bjerregaard, 2000: 401; White, Kowalski, Lyndon, Valentine, 2000: 381). Overall, a vast majority of research relies upon a definition of stalking that stresses repeated negative behavior, where the perpetrator pursues the victim on two or more occasions and where the victim perceives the behavior as undesirable. Therefore, stalking does not exist if the behavior occurs only once, and if the victim perceives the behavior and relationship as positive (Meloy, 1996:151).

Stalking has been defined as follows: "constellation of behaviours involving repeated and persistent attempts to impose on another person unwanted communication and/or contact" (Mullen, Pathe, Purcell, 2000:1244); "activities which on the surface are innocuous and

\footnotetext{
${ }^{1}$ Article $\S 646.9$, California Penal Code, [1990], defined stalking as the "willful, malicious, and repeated following or harassing" of another person; https://codes.findlaw.com/ca/penal-code/pen-sect-646-94.html, accessed 10/8/2020.

${ }^{2}$ Many states generally followed California's definition of stalking and several states reproduced parts of the California stalking law. While some states consider stalking either as a misdemeanor or a felony, other states offer varying degrees of punishment, including both misdemeanors and felonies. Further, some states require an element of threat, while other states maintain that no qualified threat is needed for the crime of stalking.
} 
commonplace but which, when constituting a course of conduct and with the necessary intent, form the basis of the criminal offence" (Bjerregaard, 2000:401); "when one person causes another a degree of fear or trepidation by behaviour which is on the surface innocent but which, when taken in context, assumes a more threatening significance" (Tjaden, Thoennes, 1998: 134); "the willful, malicious, and repeated following and harassing of another person that threatens his or her safety" (Meloy, Gothard, 1995: 258). In order to define stalking, each of these definitions, taken from the legal, psychological and sociological arenas, draws upon quite different criteria.

In general, researches agree that a comprehensive definition of stalking includes three elements: 1) a pattern of repeated conduct; 2) unwanted conduct which is experienced as intrusive by the victim, and 3) conduct which includes an implicit or explicit threat which places the victim at some level of fear. Before we analyze these element, it may be interesting to outline the empirical developments. Namely, amidst of the academic and legal debate about definitions and various classifications of stalking, empirical research has generated several other terms which either replace or supplement the term "stalking."

Some scholars intentionally avoid using the term "stalking"; they indicate that individuals often have misconceptions, misinterpretations, and preconceived notions about the word and, therefore, the use of the term "stalking" may not be an appropriate label for the desired outcome (Emerson, Ferris, Gardner, 1998:291). Some authors argue that the use of the term "stalking" limits the breadth of behaviors respondents should consider as negative and intrusive (Haugaard, Seri, 2003: 285). Other terms that have been used to refer to stalking (which come from different definitions) include "obsessional following" (Meloy, 1996: 148), "obsessive relational intrusions" (Spitzberg, Cupach, 2003: 346), "obsessional harassment” (Rosenfeld, 2004: 9), "unwanted pursuit behaviors" (Langhinrichsen-Rohling, Rohling, 2000: 459), and "intrusive contact" (Haugaard, Seri, 2003: 287).

The use of these terms have considerably aggravated the provision of the standard definition of stalking because introducing a new term with a corresponding new definition may render the analysis of research findings difficult or impossible. On the other hand, the addition of new stalking-related terms and definitions may provide beneficial contributions to the literature by introducing alternatives which may clarify the confusion associated with the term "stalking." The use of alternative stalking terms may also exclude the need to consider legal variations across different jurisdictions. The use of new terms which replace the term "stalking" appears to best suit the research testing of specific concepts that may not be legally qualified as stalking (such as intrusive forms of behavior that do not occur repeatedly). Some authors speculate that the term "stalking" may alter the responses of research participants' and, therefore, may be inappropriate for research purposes, has been challenged (Haugaard et al., 2003: 301).

\subsection{The Commission of Stalking}

Stalking is a crime that does not entail a single act. In most countries, the definition of this offence envisages the "repeated", "continuous", "persistent" or ongoing actions "over a longer period of time". However, legislative solutions do not provide even an approximate answers to the question of how many times the action must be repeated, or what is considered a longer time period. Some authors suggest that the actions constituting the crime of stalking must be repeated at least twice a week for at least six months (Zona, Sharma, Lane, 1993: 895). Other authors argue that stalking consists of at least ten separate 
actions or attempts to establish communication with the victim for a period of at least four weeks (Mullen, Pathe, Purcell, 2000: 167).

To avoid over-attribution, some researchers advocate for the commission of ten separate acts (Wright et al., 1996: 489). The problems associated with under-attributing stalking are likely to be more pronounced when intrusions are threatening and therefore may meet intent and fear requirements; however, they do not occur at least ten times. For example, research conducted by Thompson and Dennison indicates that many potential stalkers perpetrate threats and violence but did not engage in at least ten intrusions. At the same time, two or more intrusions were normative in the sample. To balance issues of over-attribution and under-attribution, Thompson and Dennison suggest a cut-point of five or more intrusions. This cut-point identified less common behavioural patterns than a cut-point of two intrusions. Concurrently, this cut-point identified much more violent and threatening behaviour than the stringent cut-point of ten (Thompson \& Dennison, 2008: 485).

Others researchers incorporate temporal requirements in their operationalisation of stalking in addition to a threshold for repetition (one month, four weeks and two weeks respectively) (Mullen et al., 2000: 167). While there is some evidence that stalking that persists for greater periods may be more harmful, aggressive and violent, recent research suggests that the impact of duration on the nature of stalking behaviour may be minimal once the effect of repetition is accounted for (Thompson et al., 2008: 490). Consequently, some researchers suggest that the answer to this question is best appreciated on a case-bycase basis, in the context of the circumstances of the specific case and the relationships between the offender and the victim.

The legislative solutions also differ in terms of the technique of prescribing the act of stalking. According to the lex certa principle, some countries have chosen to explicitly stipulate the possible actions that constitute the commission of this crime. Other states have preferred to envisage broader definitions and consequences, including examples of actions which may constitute the commission of this crime. The first method is justified by the need to protect the principles of legality and legal certainty. On the other hand, many authors point out that the stalkers are very creative in finding ways to avoid being blamed and punished in situations where there is a statutory limitation on the act of commission. In particular, there is a time limit for the prosecution of stalkers using new information technologies, which significantly contribute to the development of new tactics of stalking (Mullen et al, 2000: 171). The second method provides for a wider range of unlawful activities that may be qualified as stalking; thus, it prevents the stalker from avoiding criminal liability for the committed act(s).

\subsection{Effect on the Victim}

One of the controversial issues is whether the victim must have a subjective feeling of fear for the safety, anxiety, agitation or frustration as a result of stalking. Some authors believe that the sense of fear in the victim is the basic element of stalking. Without this element, certain behavior could be qualified as harassment, but not as stalking. In their opinion, the concept of stalking fundamentally entails the experience of the person who is the object of unwanted attention, i.e. the disturbing behavior which causes fear (Owens, 2016: 2196).

On the other hand, many authors believe that a significant number of victims would remain unprotected if the victim's fear were prescribed as an element of the offense. In a 
survey including 1,430 respondents who considered themselves victims of stalking, only $36 \%$ said that they experienced the subjective feeling of fear. Over $60 \%$ of the respondents did not meet the legal criteria for victims because they did not feel fear (Tjaden et al., 1998: 143). In order to make this element more objective, some jurisdictions introduced the concept of "a reasonable person" as a criterion. Thus, the victim does not have to prove that he/she has experienced fear, anxiety or any other consequence of stalking. It is sufficient for the court to assess, on the basis of all the circumstances of the specific case, whether anxiety and fear exist from the viewpoint of a "reasonable, rational person" (Tjaden et al., 1998: 143).

Given the fact that the criminal offence of stalking is still in the developmental stages in terms of legal issues and characteristics, empirical research is likely to continue to address the conceptual framework issues. Considering the growing interest in research on stalking and the changing legislation on this legal matter, it is anticipated that research definitions and laws addressing stalking will become more sophisticated and homogenous in the future.

\section{EMPIRICAL FINIDINGS ON STALKING}

Stalking is an inherently difficult concept to define due to its paradoxical status, which concurrently involves a criminal activity and normative conformity. In cases of stalking, the behaviour causing concern is often not so much a breach of normative conventions as an undue amplification or emphasizing of normative conformity (Mullen et al, 2000: 173). For this reason, stalking is commonly defined as repeated conduct causing fear and anxiety. Inter alia, such conduct includes practices such as following, watching, telephoning or otherwise contacting another person; loitering nearby, watching, approaching or entering a place where another person lives, works or visits; interfering with property in the possession of another person; and leaving or giving offensive material to another person (Meloy et al., 1995:258).

Differences in stalking legislation across jurisdictions relate primarily to the nature of intent. Some jurisdictions use objective tests of intent, where "a reasonable person" should have known that his/her conduct caused apprehension and fear. Other jurisdictions use subjective tests of intent, where the stalker must have intent to cause apprehension or fear in another person, while some other jurisdictions use a mixture of the two tests in prescribing the aggravated forms of this criminal offence.

Most research on stalking has focused on psychological characteristics of stalking. Here are some of the principal findings. Approximately $10 \%$ of people have experienced stalking-type behaviours at some time in their life. Victims are most likely to be female and younger than their stalkers. Stalkers are most likely to be male and older than the average male criminal (39). The majority of stalkers appear to pursue their ex-partners, and most stalking episodes last between 1 and 2 years (on average). Partner stalking is often initiated during the relationship. For example, Tjaden and Thoennes found that $57 \%$ of stalking victims were stalked during the relationship. McFarlane et al found that between $63 \%-69 \%$ of attempted femicide (women murdered or almost murdered by their partner) or actual femicide victims were stalked while in the relationship. The most common behaviours involve being watched, followed and telephoned, with the motivations for stalking being predominantly control and intimidation (Meloy et al., 1995: 260). 
Typologies of stalkers vary, and they can be based on different variables: the characteristics of the victim (e.g. celebrities and strangers); the relationship between the stalker and the victim (e.g. co-workers, acquaintances, online acquaintances and expartners); the stalker's motivation (e.g. revenge, jealousy and rejection); and the stalker's psychological profile (e.g. erotomanic and simple obsession). Many researchers use a combination of these variables in their typologies. However, the most commonly used classification is that of: stranger, acquaintance and intimate (Meloy et al., 1995: 261).

The primary recommendation of previous research findings is that the range of available responses to stalking needs to be expanded. Given the multifaceted nature of this criminal offence, one-sided interventions based either on therapy or criminal justice intervention are neither sufficient nor suitable. There is a need for more extensive cooperation between different stakeholders (including mental health experts, police and the judiciary, organisations for the prevention of domestic violence and others) in implementing the most appropriate forms of interventions. These interventions should be based on a sound understanding of different types of stalking behaviours, the potential for violence, and the detrimental impact of these behaviours upon victims, particularly when they continue over a number of years (Tjaden et al., 1998: 145).

The importance of providing a supportive environment for victims who have become isolated and experienced fear is crucial. It is only through this sort of co-operation between community, criminal justice, academic and legislative bodies that stalking will ultimately be understood and, hence, better responded to.

Last but not least, given that stalking occupies such a problematic position on the continuum between the conformist and the criminal, enhancing our understanding of the phenomenon is likely to reveal something important about ourselves and our culture.

\section{INSTEAD OF A CONCLUSION}

Stalking is one of the most serious and socially dangerous criminal offences. The concept of stalking is still incompletely defined, primarily due to the constant development of new information technologies and new forms of stalking (such as cyber-stalking). Researchers generally, agree that the definition of stalking should be as broad as possible to encompass the diverse new forms of stalking used by the perpetrator; the broader coverage of unlawful activities is to ensure that the stalker's conduct does not go unpunished. The researchers are divided in terms of the existence of a subjective element of fear in the victim. Considering the need to prevent abuse, the author of this paper considers that it is more appropriate to assess this element from the perspective of the victim and how he/she feels, and not from the point of view of "a reasonable person" as suggested by some authors. Thus, as there is no single definition of stalking, future research is to provide answers to many question about this phenomenon and its characteristics by analyzing individual cases from judicial practice.

\section{REFERENCES}

Bjerregaard, B.(2000). An empirical study of stalking victimization. In:Violence and Victims, 15, 389-406.

California Penal Code, [1990], available at https://codes.findlaw.com/ca/penal-code/pen-sect-646-94.html, accessed on 10/8/2020.

Dennison, S. M., Thomson, D. M. (2002). Identifying stalking: The relevance of intent in commonsense reasoning. In: Law and Human Behavior, 26(5), 543-561. 
Emerson, R.M., Ferris, K.O., Gardner, C.B. (1998).On being stalked. In: Social Problems, 45, 289-314.

Harmon, R. B., Rosner, R., Owens, H. (1995).Obsessional harassment and erotomania in a criminal court population. In: Journal of Forensic Sciences, 40, 188-196.

Haugaard, J.L., Seri, L.G. (2003). Stalking and other forms of intrusive contact after the dissolution of adolescent dating or romantic relationships. In: Violence and Victims, 18, 279-297.

Langhinrichsen-Rohling, J., Rohling, M. (2000). Negative family-of-origin experiences: Are they associated with perpetrating unwanted pursuit behaviors? In: Violence and Victims, 15, 459-471.

Meloy, J.R. (1996). Stalking (obsessional following): A review of some preliminary studies. In: Aggression and Violent Behavior, 1, 147-162.

Meloy, J.R., Gothard, S. (1995). A demographic and clinical comparison of obsessional followers and offenders with mental disorders. In: American Journal of Psychiatry, 152, 256-263.

Mullen, P.; Pathe, M.; Purcell, R. (2000). Stalkers and their Victims, Cambridge University Press, London, pp. 164-173.

Owens, J. G. (2016). Why definition matter: Stalking victimization in the United States, In: Journal of Interpersonal Violence, 31 (12), 2016, pp. 2196-2226

Ristanović Nikolić V., Lepojić Kovačević I., (2007). Proganjanje: pojam, karakteristike i društveni odgovori (Stalking: notion, characteristics and social response), In: Temida br. 4, Viktimiološko društvo Srbije, Beograd, pp. 3-12.

Rosenfeld, B. (2004). Violence risk factors in stalking and obsessional harassment: A review and preliminary meta-analysis. In: Criminal Justice and Behavior, 31, 9-36.

Sheridan, L., Gillett, R., \& Davies, G., (2002).Perceptions and prevalence of stalking in a male sample. In: Psychology, Crime and Law, 8, 289-310.

Spitzberg, B.H., \& Cupach, W.R. (2003). What mad pursuit? Obsessive relational intrusion and stalking related phenomena. In: Aggression and Violent Behavior, 8, 345-375.

Thompson, C. M., \& Dennison, S. M. (2008). Defining Relational Stalking in Research: Understanding Sample Composition in Relation to Repetition and Duration of Harassment. In: Psychiatry, Psychology and Law, 15(3), 482-499.

Tjaden, P., Thoennes, N., (1998). Stalking in America: finding from the National Violence Against Women survey 5, Washington, DC: National Institute of Justice, pp. 131-147.

Van der Aa, S. (2010). Stalking in the Netherlands. Nature and Prevalence of the Problem and the Effectiveness of Anti-Stalking Measures, Makly, Antwerpen,

Van der Aa, S, (2017). New trends in the Criminalization of Stalking in the EU Member States, Tilburg University, Tiloburg 2017, pp. 96-116.

White, J., Kowalski, R.M., Lyndon, A., \& Valentine, S. (2000). An integrative contextual developmental model of male stalking. In: Violence and Victims, 15, 373-388.

Wright, J.A., Burgess, A.G., Burgess, A.W., Laszlo, A.T, McCrary, G.O., \& Douglas, J.E. (1996). A typology of interpersonal stalking. In: Journal of Interpersonal Violence, 11, 487-502.

Zona M., Sharma K., Lane J., (1993). A comparative study of erotomanic and obsessional subjects in a forensic sample, In: Journal of Forensic Sciences, 38, pp. 894-903.

\section{PROGANJANJE - TEORIJSKI PREGLED}

Poslednjih godina sve veću pažnju naučne i stručne javnosti privlače slučajevi proganjanja. On je prepoznato kao zločin i kao ozbiljan društveni problem devedestih godina. Pre toga, nijedna država, društvo nije inkriminalo proganjanje kao krivično delo. To ne znači da proganjanje nije postojalo. Meloj smatra da je proganjanje oduvek postojalo u društvu među ljudima. Pre donošenja zakona koji proganjanje propisuju kao krivično delo, mnoga ponašanja koja predstavljaju proganjanje su smatrana uznemiravanjem. Zanimljivo je da je medijski portret proganjanja poznatih ličnosti bio katalizator koji je prvo otkrio postojanje ovog ponašanja i rasplamsao globalnu pažnju. Autor u ovom radu daje pregled šta se smatra proganjanje, iznosi argumente za njegovu inkriminaciju kao krivičnog dela i sumira najvažnije karakteristike do kojih se došlo na osnovu sprovedenih istraživanja.

Ključne reči: proganjanje, krivično delo, fenomen, karateristike 